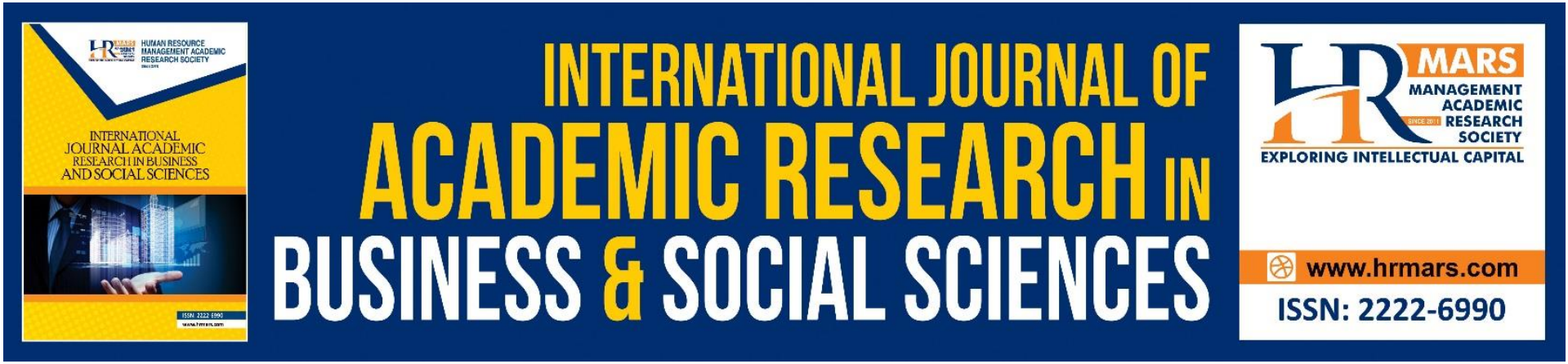

\title{
KKQ Teacher's Knowledge of Students' Background in Teachingthe Quranic Tajweed Subject in Klang Valley Region
}

Jahidih Saili

To Link this Article: http://dx.doi.org/10.6007/IJARBSS/v11-i4/9701

DOI:10.6007/IJARBSS/v11-i4/9701

Received: 09 February 2021, Revised: 14 March 2021, Accepted: 26 March 2021

Published Online: 20 April 2021

In-Text Citation: (Saili, 2021)

To Cite this Article: Saili, J. (2021). KKQ Teacher's Knowledge of Students' Background in Teachingthe Quranic Tajweed Subject in Klang Valley Region. International Journal of Academic Research in Business and Social Sciences, 11(4), 562-574.

Copyright: @ 2021 The Author(s)

Published by Human Resource Management Academic Research Society (www.hrmars.com)

This article is published under the Creative Commons Attribution (CC BY 4.0) license. Anyone may reproduce, distribute, translate and create derivative works of this article (for both commercial and non-commercial purposes), subject to full attribution to the original publication and authors. The full terms of this license may be seen at: http://creativecommons.org/licences/by/4.0/legalcode

Vol. 11, No. 4, 2021, Pg. 562 - 574

Full Terms \& Conditions of access and use can be found at http://hrmars.com/index.php/pages/detail/publication-ethics 


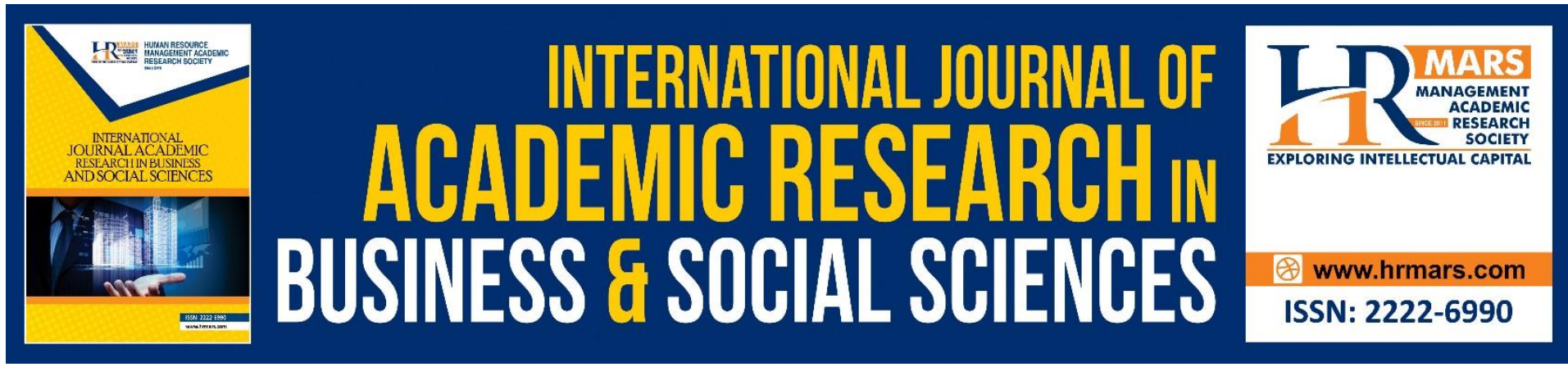

\title{
KKQ Teacher's Knowledge of Students' Background in Teachingthe Quranic Tajweed Subject in Klang Valley Region
}

\author{
Jahidih Saili \\ Universiti Teknologi MARA Sabah Branch, Kota Kinabalu Campus \\ Malaysia \\ Email: jahidihsaili@uitm.edu.my
}

\begin{abstract}
The aim of this study is to identify teacher's level of knowledge of students in teaching Quranic Tajweed subject in a Special Skill Lesson in Recitation and Memorizing the Quran (KKQ) in the Klang Valley Region. A total of $43 \mathrm{KKQ}$ teachers participated in this study. This quantitative study used a survey research design and the research data obtained by using the questionnaire instrument. The validity of data is done by setting up a reference panel of experts. Data were analyzed by descriptive and inferential to get the frequency value, percentage, mean, standard deviation, t-test and ANOVA. A pilot study was conducted and it was found that the reliability of the instrument by Cronbach's alpha is at a high level of $>0.80$. Overall, KKQ teachers' knowledge of their students is high. T-test analysis across gender, teacher's university background, Sanad certification, and location of school indicates that the significant differences exist only in teachers' universities background. It is found that KKQ teachers (graduated from foreign universities) have higher level of knowledge of their students than teachers graduated locally. While ANOVA analysis in terms of teaching experience, found that there is no significant differences in the level of knowledge of student among the KKQ teachers in this aspect. This implies, KKQ teachers level of knowledge of their students needs to be upgrade from time to time. Differences based on teachers' university background should be a key consideration by authorities in dealing with any issue or planning related to Quranic Tajweed lesson.
\end{abstract}

Keywords: Quranic Tajweed, Pedagogical Content Knowledge

\section{Introduction}

Teaching is a process of imparting of knowledge from a teacher to his students. This process usually involves various activities such as planning, implementation, evaluation and feedback (Hashim, Yaakub, \& Ahmad, 2003). It should be well planned (Ahmad, 2000) in order to obtain an effective teaching, thus able to gain an effective learning in a classroom (Al-Shaibani, 1991).

As Muslims, we believe that the Prophet Muhammad (peace be upon him) is the greatest teacher and educator of all time. Teaching process carried out by him is easily 
comprehended by the mind and affect immensely the heart of each student (Fattah, 2011). Among the key factors emphasized by him in his teaching was the students' background (Fattah, 2011). This factor is important in ensuring an effective teaching is achieved since each student has a different background and therefore require different approaches (Yusuf alQardhawi, 2003). Hence, Allah's Messenger suggested some aspects such as time, circumstances and teaching materials must be adaptable to each students' background (Hamm, 2012). His attitude in emphasizing on students' background should be an example to follow especially because he is the best role model in every aspects including in the implementation of teaching (Mamat, 1997).

\section{Research Background}

Teaching Tajweed is an important component in KKQ lessons which aims to expose students to various methods of controlling the (Arabic) alphabet and reciting verses of the Quran correctly in accordance to the rules of Tajweed. Students who master this skill are able to recite Quran properly according to rules and procedures of a proper recitation (JAPIM, 2005). Teaching Quranic Tajweed should involve various methods such as demonstration by teachers and correcting students' error in recitation of Quran (Hashim, Yaakub, \& Ahmad, 2003), since this subject is a skill based lesson (Ministry of Education, 2004). The effectiveness of this teaching method depends on the KKQ teacher's level of knowledge of the students' background itself. This is because, the knowledge of the students' background is one of the important component of knowledge in creating an effective (Quran) teaching (Shulman, 1987; Ibn Khaldun, 2000; Fattah, 2011; Kassim, 2011).

KKQ implementation has spanned for 29 years and is still facing various problems related to teaching including on KKQ teacher's knowledge of students' background in Quranic Tajweed lesson. Previous study has found that this vulnerability is not limited to KAA school but it also applies to all schools in Malaysia which implement KKQ method (Noh, 2011). These should not have happened since Quran has an important role and impact in the lives of every Muslims. KKQ teaching system, particularly in teaching Quranic Tajweed should be improved in order to enhance students' mastery in sciences of the Quran. Of course, one of the ways to materialize this vision is by upgrading the KKQ teachers' knowledge regarding their students' background in the Quranic Tajweed teaching.

\section{Problem Statement}

Teachers' knowledge of students is a determine factor to an effective teaching in a classroom. This will leads to awareness in students learning style as well as other aspects related to students such as interests, abilities, attitudes, beliefs and learning problems encountered by them (Ibn Khaldun, 2000). This information is important as it helps teachers in selecting suitable teaching contents and pedagogy that can be applied during teaching and learning process, including in Quranic Tajweed lesson (Zamri, 2011). Teaching contents and pedagogy presented to students must be compatible to students' cognitive level, students' acceptance level, students' short coming, students' common mistakes, level of difficulty and students' facilities (Mark, 1990). Teachers should avoid teaching non-suitable subject matter that is not compatible with the ability of students' mind or background, to prevent students from getting bored, confused and misused the knowledge they gained (al-Ghazali, 1939).

In the context of Quranic Tajweed teaching, KKQ teachers often face problems in 
understanding students' knowledge since teachers have less exposure in this aspect of discipline (Salleh, 2007; Mat, 2010). According to Salleh (2007) and Mat (2010), on average level the KKQ teachers have less exposure and involvement in relevant courses pertaining to KKQ. As a matter of fact, some of these teachers have never attended any courses on this subject (Salleh, 2007 \& Mat, 2010). It is a bit awkward for a Tajweed teacher since the main factors affecting students' ability to read Quran according to the rule of Tajweed beside the parents, are teachers themselves. Furthermore, teachers are implementing agent to a teaching process (Abdullah, 2000). Thus, success measurement in a learning process, including Quranic Tajweed lesson is determined by the teachers themselves. Previous studies have shown that there were a number of KKQ teachers while delivering their teachings did not observe the differences occur among students. This is especially in terms of cognitive knowledge and students' ability in accepting the subject content. In addition, some of these teachers delivered high level subject content, as well as too much subject content are delivered to students at any one time (Mat, 2010).

Hence, this study was undertaken to determine KKQ teachers' level of knowledge of their students' in Quranic Tajweed teaching. This research is vital in order to verify in detail the level of knowledge among KKQ teachers about their students' in Quranic Tajweed teaching as well as to identify weaknesses among teachers in this subject. It is also necessary since no such study is available on Quranic Tajweed teaching yet. An overview in this field of study that was done on KKQ also show, research on KKQ teachers' knowledge of their students have never been done for other component subjects such as memorizing the Quran, 'ulum al-Quran, qira'at sab'ah and tarannum.

\section{Research Objectives}

This study aims to achieve objectives that have been outlined as follows:

i. To acknowledge the level of knowledge among KKQ teachers about their students in Quranic Tajweed lessons.

ii. To identify the different levels of knowledge among KKQ teachers about their students based on demographic aspects such as:
a. Gender
b. Universities background
c. Sanad certification
d. Location of school
e. Teaching experience

\section{Research Hypotheses}

This study has several hypotheses as follows:

$\mathbf{H}_{\mathbf{0 1}}$ There is no significant difference in mean scores for KKQ teachers' level of knowledge about their students by gender.

$\mathbf{H}_{\mathbf{0 2}}$ There is no significant difference in mean scores for KKQ teachers' level of knowledge about their students based on university background.

$\mathbf{H}_{\mathbf{0} 3}$ There is no significant differences in mean scores for teachers' level of knowledge about their students based on Sanad certification. 
$\mathbf{H}_{\mathbf{0}}$ There is no significant differences in mean score for teachers' level of knowledge about their students based on location of school.

$\mathbf{H}_{05}$ There is no significant differences in mean score for teachers' level of knowledge about their students based on teaching experience.

\section{Research Methodology}

This study used a descriptive and inferential study design performed in a quantitative form. This study design is suitable in explaining a phenomenon that is taking place in areas that have not been studied (Konting, 2005). Furthermore, the implementation of studies using this study design has very high validity (Neuman, 2003). This study design is suitable for this study because it meets the objectives, i.e. to identify the level of knowledge among teachers about their students. It can also to verify factors pertaining different levels of knowledge among teachers about their students in Quranic Tajweed teaching. In this study, the quantitative data were collected using survey method in accordance with a large number of respondents (Ary, 2002). Questionnaires were constructed and distributed to the teachers and data were collected then. These respondents were brief in advance on the aim of this study and how to response to questionnaires. Next, respondents were required to answer the questionnaires within a flexible time. After completion, the questionnaires were collected from respondents.

The study population consist of $30 \mathrm{KKQ}$ teachers from $30 \mathrm{KAA}$ schools in the Klang Valley Region. Survey population of this study area, i.e. the Federal Territory of Kuala Lumpur is 18 teachers from 17 KAA school (Islamic and Moral Education Department, 2011). The size of this population does not meet a normal distribution for quantitative research requirement which is 30 samples or more (Som, 2005). Hence, population size is added by several KAA schools in the Klang Valley Region for the district of Hulu Langat, Gombak, Petaling and Klang. Sampling technique used for the main study area is a sampling technique that involves the entire population (Ghafar, 1999). This means, the sample for the main study area were 18 KKQ teachers. While research samples for the main study area which involved around Klang Valley were determined by using random cluster sampling. This sampling technique does not use direct sampling techniques to all members of a population but instead make the location or institution where the samples are as a group (Talib, 2013). Questionnaires were distributed to more than $12 \mathrm{KAA}$ schools to avoid survey errors such as questionnaire not being returned. Based on the above entire population sampling techniques and random cluster sampling technique, it was found that the overall number of samples involved in this study were 43 respondents.

The validity of questionnaire instruments is determined by establishing panel of expert consisting of four individual who are expert in the field of Islamic Education, Quranic education and in the field of research to ensure the validity of the content and face validity. The reliability of instrument refers to the internal consistency of items used in the instrument (Gall, Gall \& Borg, 2005). In the context of this study, the internal consistency of each instrument item was obtained by using the Cronbach's alpha coefficient. The analysis showed that all instruments in this study have a high reliability $(>0.80)$. Therefore these instruments can be used in actual study. Quantitative data analysis in this study was conducted through descriptive and inferential method, using IBM SPSS V20. Descriptive analysis is explained using mean effective behaviour interpretation tables by Nunally (1978) as shown in Table 1 below. 
Table 1. Interpretation Mean of Effective Behavioural Dimensions

\begin{tabular}{ll}
\hline Mean Score & Interpretation \\
\hline $4.01-5.00$ & High \\
$3.01-4.00$ & Moderately High \\
$2.01-3.00$ & Moderately Low \\
$1.01-2.00$ & Low \\
\hline
\end{tabular}

Source. Stufflebeam (1971)

Inferential statistical analysis is used to obtain inference from a statistical sample of the entire population. In this study, inferential analysis is carried out based on IndependentSamples T Test and One-Way ANOVA procedures to test the significance level in comparing mean scores for independent variable, i.e. teachers' demographic.

\section{Research Analysis}

\section{KKQ teachers' Profiles}

Based on Table 2 below, the numbers of teacher respondents involved in this study were 43 people. Details of respondents by gender show that the male respondents $(26=60.5 \%)$ were more than female respondents $(17=39.5 \%)$. From the aspect of university background, it shows that the teacher respondents which graduated from the local university $(29=67 \%)$ were more than the number of teacher respondents' that graduated from foreign universities (14 $=32.6 \%)$. In terms of Sanad certification, the number of respondents with Sanad certification $(11=25.6 \%)$ was less than the number of respondents without Sanad certification ( $32=74.4 \%$ ). In terms of teaching experience, the findings were more balanced. Respondents with teaching experienced more than 10 years are 14 people (32.6\%). While respondents with teaching experience between $5-10$ years was 15 people (34.9\%). This amount is not much different from the number of respondents with teaching experience between $1-5$ years, i.e. 14 people (32.6\%).

Table 2. KKQ Teachers' Profiles

\begin{tabular}{llll}
\hline Items & & Frequency & Percentages \\
\hline Gender & Male & 26 & $60.5 \%$ \\
& Female & 17 & $39.5 \%$ \\
University & Local university & 29 & $67.4 \%$ \\
background & Foreign university & 14 & $32.6 \%$ \\
Sanad certification & Yes & 11 & $25.6 \%$ \\
& None & 32 & $74.4 \%$ \\
Location of school & Urban & 25 & $58.1 \%$ \\
\multirow{2}{*}{ Teaching } & Suburb & 18 & $41.9 \%$ \\
experience & More than 10 years & 14 & $32.6 \%$ \\
& 5-10 years & 15 & $34.9 \%$ \\
\hline
\end{tabular}

KKQ teacher's knowledge level of their students in Quranic Tajweed Lessons

Table 3 below is the mean, standard deviation and interpretation for each teacher knowledge construct of students in teaching Quranic Tajweed. The total mean score of construct is 4.44, 
standard deviation is 0.31 and interpretation is high. Mean constructs with the highest turnover is knowledge construct about student attitudes (mean $=4.58, \mathrm{sp}=0.41$ ), followed by knowledge construct about students Quranic skill level (mean $=4.56, \mathrm{SP}=0.36$ ). Further is knowledge construct about student learning problems (mean $=4.51, \mathrm{sp}=0.41$ ), knowledge on students' cognitive (mean $=4.39, \mathrm{sp}=0.43$ ), knowledge on students' socio-emotional ( mean $=4.35, \mathrm{sp}=0.37$ ) and construct with lowest mean is constructs on general information about student $($ mean $=3.67, \mathrm{sp}=1.01)$.

Table 3. Teacher Knowledge Level of Students Based on Teacher and Student Perception

\begin{tabular}{lccc}
\hline Teacher Knowledge of Students & Mean & S.D & Interpretation \\
\hline General information about students & 3.67 & 1.01 & High \\
Knowledge about student cognitive & 4.39 & 0.43 & High \\
Knowledge about student socio-emotional & 4.35 & 0.37 & High \\
Knowledge about student learning problem & 4.51 & 0.41 & High \\
Knowledge about student attitude & 4.58 & 0.41 & High \\
Knowledge about student Quranic Skill level & 4.56 & 0.36 & High \\
\hline Total mean & $\mathbf{4 . 4 4}$ & $\mathbf{0 . 3 1}$ & High \\
\hline
\end{tabular}

\section{Mean score differences on teacher knowledge level of student based on teachers demographics}

The T-test analysis results in Table 4 below shows that there is no significant differences in mean scores $(P=0290, p<0.05)$ of KKQ teachers' knowledge of students based on gender aspects of male (mean $=4417, \mathrm{sp}=0.289$ ) and female (mean $=4.471, \mathrm{sp}=0.350$ ). Thus, $\mathrm{H}_{\mathrm{o} 1}$ is accepted. Meanwhile, the analysis of subsequent studies shows that there is a significant difference $(P=0.048, p<0.05)$ on KKQ teachers' knowledge of students in the aspect of university background of teachers, i.e. local graduate (mean $=4.401$, $\mathrm{sd}=0.340$ ) with overseas graduate teachers (mean $=4.515, \mathrm{sd}=0.234$ ). Hence, $\mathrm{H}_{\mathrm{o} 2}$ is rejected. The following analysis also found that there is no significant difference $(P=0.484, p<0.05)$ on KKQ teachers' knowledge of students in the aspect of teachers with Sanad certification (mean $=4.667, \mathrm{sp}=$ 0.257 ) and those without Sanad certification (mean $=4.360, \mathrm{sp}=0.292$ ). Thus, $\mathrm{H}_{03}$ is accepted. The final analysis shows the mean score difference is not significant $(P=0.294, p<0.05)$ in the aspect of location of school which is urban (mean $=4.445, \mathrm{sp}=0.299$ ) and suburb (mean = $4.429, \mathrm{sp}=0.336)$. With this, $\mathrm{H}_{\mathrm{o}}$ is accepted. 
Table 4. T-test Variance on Teachers Knowledge Level of Students Based on Demographics

\begin{tabular}{llllll}
\hline Teacher Demography & $\mathbf{N}$ & Min & SD & $\begin{array}{l}\text { T- } \\
\text { value }\end{array}$ & Sig. P \\
\hline Sex & & & & & \\
Male & 26 & 4.417 & 0.289 & -.587 & 0.290 \\
Female & 17 & 4.471 & 0.350 & -.525 & \\
University background & & & & & \\
Local & 29 & 4.401 & 0.340 & -1.128 & $0.048^{*}$ \\
Overseas & 14 & 4.515 & 0.234 & -1.281 & \\
Sanad certification & 11 & 4.667 & 0.257 & 3.100 & 0.484 \\
Yes & 32 & 4.360 & 0.292 & 3.304 & \\
Nil & & & & & \\
Location of school & 25 & 4.445 & 0.299 & .162 & 0.294 \\
Urban & 18 & 4.429 & 0.336 & .159 & \\
Suburb & & & & & \\
\hline
\end{tabular}

*Significant at the level of $p<0.05$

The result of one-way variance analysis in Table 5 below shows, there is no significant difference in mean score $(P=0.084, p>0.05)$ in KKQ teachers' knowledge of students based on their teaching experience. Hence $\mathrm{H}_{05}$ is accepted. Thus, post-hoc Scheffe's test does not need to be carried out.

Table 5. One Way ANOVA of Teachers' Knowledge Level of Students Based on Teaching Experience

\begin{tabular}{llllll}
\hline & JKD & DK & MKD & F & Sig. P \\
\hline Between group & .204 & 2 & .102 & 1.054 & .358 \\
In group & 3.876 & 40 & .097 & & \\
\hline Total & 4.081 & 42 & & & \\
\hline
\end{tabular}

*Significant at the level of $p<0.05$

\section{Discussion}

In general, KKQ teachers acquainted with students at a high level. Details of this study show, the level of KKQ teachers' knowledge on general information about students is moderately high. This suggests that KKQ teachers have low information about their students' family background. Similarly, in the aspect of family's economic status and residence of students, KKQ teachers' also have low knowledge in both aspects. This phenomenon is somewhat anomalous for teachers because this information will drive teachers to assess the progress and needs of students in the subject (Coombs, 2009). Teachers' knowledge on general information of students should not be limited to above aspects only, but it should be extended even into aspects such as races, country of origin and health conditions (Ali Murad, 2003).

Research analysis in an aspect of KKQ teachers' knowledge of students' cognitive aspect found that KKQ teachers have high level of knowledge in this area. This suggests that teachers can perform their teaching based on their students' Quranic Tajweed knowledge level. This study also gives the impression that KKQ teacher also adept at identifying 
differential factors among students when planning for their lessons. This is important to ensure there is consistency between teaching contents with students' cognitive level so as to enable students to absorb the contents delivered (Yussof, 2010). This can avoid misconceptions from occurring during teaching process (Kassim, 2011). After all, the practice of teaching high subject matter which contradicts to students' cognitive level is a mistake in teaching and learning process (PdP) (Al-Ghazali, 1997). KKQ teachers have high knowledge in students' cognitive level, thus explained that they are knowledgeable about students' learning style in $\mathrm{KKQ}$. Possessing this knowledge allows teachers to diversify their teaching methods. This is because KKQ students have diverse learning styles. Some of them are likely to learn through listening, while others learn by sight etc. (Felder \& Henriques, 1995).

The findings further revealed that KKQ teachers were highly knowledgeable about students socio-emotional. This means that KKQ teachers emphasize on students' socioemotional when delivering their teaching. KKQ teachers are also good at motivating students to learn Quranic Tajweed. This is also an important skill in developing self-confidence among students so they remain focused in learning this subject. Motivating students can be easily done, for example by using polite words to them, including to KKQ students (Ashaari, 2001). KKQ teachers are also good at giving instructions. Clear instructions will influence the listener, message is easily understood, and then it can be translated accordingly as required by the directives.

In terms of knowledge on students' learning problems, the research analysis found that KKQ teachers are highly knowledgeable in this area. This is important since students' learning problems have great influence on their academic performance (Yahaya \& Ismail, 2011). Learning problems in the long run will result in students' academic performance plummeted (Yahaya, 2011). Findings in aspect of this knowledge, gives an impression that KKQ teachers are competent at giving directions according to students' cognitive level. Clear directions in teaching are important to avoid students from doing anything contrary to the objectives of teaching and learning (PdP) in Quranic Tajweed lessons.

The findings further indicate that the KKQ teachers have high knowledge of students' attitudes toward Quranic Tajweed lessons. They realize that diversity in attitude directly affects students' interest on the subjects. They know that students' attitudes toward Quranic Tajweed lesson are important as a first step in improving students' negative attitude toward this subject. Such attitudes need to be changed or else it will be a stumbling block to the ongoing delivery of educational content included in the Quranic Tajweed lessons (TurnerBisset, 2004). Apart from being an obstacle in conveying educational content, this attitude is at risk in removing fun in learning Quranic Tajweed. As a matter of fact, fun aspect is a key element in pedagogy (Turner-Bisset, 2004). Thus, a positive attitude towards a subject must be nurtured because it has a great impact on students' achievement in any subject. This occurs because students' positive attitude towards any subjects can stimulate them to master the subjects (Turner-Bisset, 2004).

The final analysis on knowledge aspect shows that the KKQ teachers have high knowledge regarding on students' Quranic skill level. Renzulli \& Reis (1993) describes that one of the meaning of knowledge is to learn about something by recalling, recognizing, distinguishing, translating, interpreting, clarifying facts, theories, concepts and principles. In 
learning and teaching (PdP) context for Tajweed lessons, a teacher needs to access students' Tajweed skill level to the extent of being able to recall, recognize and differentiate different aspects of Quranic Tajweed skills that have been mastered by them. It was also found that KKQ teachers able to identify students' prior knowledge in Quranic Tajweed subject. This knowledge refers to past experience, either directly or indirectly, and remained in the memory of students. This knowledge is important in order to establish a framework of knowledge to facilitate assimilation of new knowledge (Nawawi, 2005). In the context of Quranic Tajweed teaching, KKQ teachers always relate previous lesson with present lesson through various activities such as $Q$ \& $A$ and others. Among the practices of KKQ teachers in identifying students' skill levels in Quranic Tajweed lesson is to show interest in students examination result and concern about problems facing by students during learning process. Focus on both of these aspects help teachers to plan better and take necessary measures to rectify the shortcomings encountered by students, thus they are able to increase their commitment to keep learning (spiritual, 2010).

The differential analysis found that, there is no difference in the level of knowledge among KKQ teachers regarding students based on teachers' demographics aspects such as gender, Sanad certification, location of school, and teaching experience. Instead, different levels of knowledge among KKQ teachers of their student is only limited to universities background. Detail result of this study shows that KKQ teachers graduated from foreign universities have more knowledge of their students than KKQ teachers graduated locally.

\section{Research Implications}

The overall findings of this study indicate that KKQ teachers have high level of knowledge of their students. This level of knowledge should be maintained or enhanced periodically by implementing further measures such as conducting courses related to Quranic Tajweed curriculum. On the other hand, KKQ teachers must give full commitment while undergoing those courses. One-sided effort is not effective in upgrading teachers' pedagogical knowledge in Quranic Tajweed lessons, instead both sides must involved, i.e. the organizers and KKQ teachers themselves. Detailed findings for each construct show that KKQ teachers have moderately high level of knowledge pertaining to general information about students. This finding indirectly suggests that KKQ teachers do not have satisfactory knowledge regarding to construct of knowledge. Teachers' needs to improve in this area because this aspect is important when considering and selecting lesson content and pedagogical design that would be presented to students. A deep knowledge in this area will undoubtedly improve the effectiveness of teaching Quranic Tajweed. Ultimately, it will improve students' achievement in KKQ lessons.

Differential analysis found, demographic factors such as gender, Sanad certification, location of school and teachers' teaching experience did not contribute to differences in the level of knowledge about curriculum among the KKQ teachers. On the contrary, differential analysis based on demographic in the aspect of university background among teachers indicates that teachers graduated from foreign universities have better knowledge regarding their students compare to teachers graduated from local universities. This finding implies that universities or educational background of the teacher is a contributing factor to the differences in teachers' level of knowledge regarding to student. This reality is useful information to the authorities, especially the Ministry of Education and school administrators to take appropriate measures in response to these findings. Further study should be 
conducted to identify the effectiveness of KKQ teacher training program received by them. The authorities should review the curriculum adopted by KKQ teachers when they were in higher education institutions. Naturally, Quranic education curriculum adopted by teachers from foreign universities should be studied and then applied to the future KKQ teachers who study at local universities. There is a suggestion to recruit more graduates from universities abroad, especially from middle east university so the number of KKQ teachers increases, especially in teaching Quranic Tajweed.

\section{Conclusion}

Generally, the objectives outlined in this study have been answered. The KKQ teachers are found to have high level of knowledge of their students. However, they should increase their knowledge regarding general information about their students because it was found that their knowledge in this aspect to be unsatisfactory. The inferential study found that, teachers' educational background contributes to the different levels of knowledge among teachers regarding to students background in Quranic Tajweed lessons. KKQ teachers graduated from universities abroad have high level of knowledge of students compared to their colleagues graduated locally. This aspect needs to be addressed by taking further actions such as conducting research on al-Quran education curriculum adopted by KKQ teachers while studying in higher education institutions. It is fair to recruit more graduates from universities abroad to teach KKQ lesson.

\section{Corresponding Author}

Jahidih Saili

Universiti Teknologi MARA Sabah Branch, Kota Kinabalu Campus Malaysia

Email: jahidihsaili@uitm.edumy

\section{References}

Al-Quran al-Karim

Abdullah, M. R. (2000). Penilaian pelaksanaan kurikulum al-Azhar di sekolah menengah agama Jabatan Agama Islam Selangor. Tesis Sarjana. Universiti Malaya.

Ahmad, M. Y. (2000). Sejarah dan Kaedah Pendidikan al-Quran. Kuala Lumpur: Penerbitan Universiti Malaya.

Arbaa, R., Jamil, H., \& Razak, N. A. (2010). Hubungan guru-pelajar dan kaitannya dengan komitmen belajar pelajar: Adakah guru berkualiti menghasilkan perbezaan pembelajaran antara jantina pelajar? Jurnal Pendidikan Malaysia, 35 (2), 61-69.

Ary, D., Jacobs, L. C., Razavieh, A. (2002). Introduction to research in education. Belmont USA: Wadsworth/Thompsom Learning.

Ashaari, M. (2001). Strategi Pendekatan Penyayang dalam pendidikan. Jurnal Pendidikan Islam, 9 (3), 1-7.

Coombs, B. (2009). Mengajar secara efektif. Terj. Institut Terjemahan Negara Malaysia Berhad. Kuala Lumpur: Institut Terjemahan Negara Malaysia Berhad.

Fattah, A. S. A. (2011). Nabi Muhammad guru dan pendidik terulung. Terj. Hj. Shuhadak Mahmud. Bahau: M Khari Enterprise.

Felder, R. M., \& Henriques, E. R. (1995). Learning and Teaching Styles in Foreign and Second Language Education, Foreign Language Annals, 28 (1), 21-21.

Gall, J. P., Gall, M. D., \& Borg, W. R. (2005). Applying educational research a practical guide. Boston: Allyn and Bacon. 
Ghafar, M. N. A. (1999). Penyelidikan pendidikan. Skudai, Johor. Penerbit Universiti Teknologi Malaysia.

Hamm, I. M. (2012). Islamic Perspective of Education and Teachers. European Journal of Social Sciences 30(2): 223-235.

Hasan, A. S. M. (2008). Kelas Kemahiran al-Quran (KKQ) di SMKA Falahiah Pasir Pekan: Tinjauan mengenai metodologi pengajaran dan keberkesanannya. Tesis Sarjana, Universiti Malaya, Kuala Lumpur.

Hashim, S., Yaakub, R., \& Ahmad, M. Z. (2003). Pedagogi: Strategi dan Teknik Mengajar Dengan Berkesan. Bentong: PTS Publications \& Distributors Sdn. Bhd.

Ibn Khaldun. (2000). Muqadimah Ibn Khaldun. Terj. Kuala Lumpur: Dewan Bahasa \& Pustaka. Jabatan Pendidikan Islam dan Moral, KPM. (2005). Kurikulum Kelas Khas Kemahiran Membaca dan Menghafaz al-Quran. Putrajaya. Bahagian Kurikulum Pendidikan dan Moral.

Kassim, A. Y. (2011). Pengetahuan pedagogikal kandungan (PPK) pengajaran akidah: Kajian kes guru cemerlang pendidikan Islam. Tesis PhD, Universiti Kebangsaan Malaysia, Bangi.

Kementerian Pelajaran Malaysia. (2004). Kurikulum Kelas Khas Kemahiran al-Quran, Tingkatan satu, dua dan tiga. Kuala Lumpur: Bahagian Kurikulum Pendidikan Islam dan Moral, Jabatan Pendidikan Islam dan Moral, Kementerian Pendidikan Malaysia.

Konting, M. J. (2005). Kaedah penyelidikan pendidikan. Kuala Lumpur : Dewan Bahasa dan Pustaka.

Mahamod, Z. (2011). Inovasi P\&P dalam pendidikan Bahasa Melayu. Tanjung Malim: Penerbit Universiti Pendidikan Sultan Idris.

Mamat, I. (1997). Memimpin remaja sekolah teori dan praktik. Kuala Lumpur: Kumpulan Budiman Sdn. Bhd.

Mat, E. (2010). Kelas Khas Kemahiran al-Quran (KKQ): Kajian kaedah pelaksanaan dan keberkesanannya di Sekolah-Sekolah Menengah (SMK) di Daerah Gombak, Selangor. Tesis Sarjana. Akademi Pengajian Islam. Kuala Lumpur: Universiti Malaya.

Mark, R. (1990). Pedagogical content knowledge: From mathematical case to modified conception. Journal of Teacher Education, 41 (3), 11.

Nawawi, S. H. M. (2005). Perbandingan pencapaian dan sikap pelajar dengan tahap pengetahuan sedia ada dalam kajian rekaan seni visual. Tesis Sarjana, Universiti Pendidikan Sultan Idris, Perak.

Neuman, W. L. (2003). Social Research theory methods: Qualitative and quantitative (Edisi Ke-5). New York: Pearson Education Inc.

Noh, M. A. C. (2011). Pelaksanaan Kelas Kemahiran Al-Qur'an Di Malaysia: Satu Analisis. Journal of Islamic And Arabic Education, 3 (1) 47-58. UKM: Bangi.

Nunally, J. C. (1978). Psycometric theory. New York: Mc. Graw Hill Book Company.

Renzulli, J. S., \& Reis, S. M. (1993). Developing Creative Productivity Through the Enrichment Triad Model. Dalam Isaksen S.G., Murdock, M.C., Firestein, R.L., Treffinger, D.J. (Eds) Nurturing and Developing Creativity: The Emergence of A Discpline. New Jersey: Ablex Publishing.

Turner-Bisset, R. (2004). Pengajaran pakar. Kuala Lumpur: Institut Terjemahan Malaysia.

Salleh, M. S. (2007). Penyeliaan Kelas Kemahiran al-Qur'an di Sekolah Menengah Kebangsaan: kajian di Jabatan Pendidikan Kelantan. Tesis Sarjana. Akademi Pengajian Islam. Kuala Lumpur: Universiti Malaya. 
Sapar, A. A., Salim, N. R., Husin, A. F., \& Pa, M. T. (2013). Penguasaan pelajar sekolah menengah terhadap kata pinjaman bahasa arab berasaskan pengetahuan sedia ada. Online Jurnal Of Islamic Education, 1 (1).

Said, H., \& Rasid, R. A. (2011). Amalan penyeliaan pengajaran dan pembelajaran di sekolahsekolah kebangsaan di daerah Melaka Tengah, Melaka. 1-9. (Unpublished)

Som, H. M. (2005). Panduan mudah analisis data menggunakan SPSS Windows. Johor: Penerbit Universiti Teknologi Malaysia.

Shulman, L. S. (1987). Knowledge and teaching: Foundations of the new reform. Harvard Educational Review 57: 1-22.

Shulman, L. S. (1986). Those who understand: Knowledge growth in teaching. Educational Researcher 15 (2): 4-14.

Talib, O. (2013). Asas penulisan tesis penyelidikan dan statistik. Selangor: UPM Press.

Yahaya, A., \& Ismail, N. (2011). Faktor-faktor pemilihan kursus dan masalah-masalah pembelajaran dalam mempengaruhi pancapaian akademik pelajar tingkatan empat aliran teknikal di tiga buah sekolah menengah teknik di Negeri Sembilan. Journal of Technical, Vocational \& Engineering Education, 2, 93-106.

Al-Qardhawi, Y. (2003). Sunnah: Sumber ilmu dan peradaban. Penterjemah. Muhammad Firdaus. International Islamic Thought Malaysia. Selangor.

Yussof, A. S. (2010). Idea-idea pendidikan berkesan al-Ghazali dan Konfusius. Bangi: Penerbit UKM. 